\title{
Common problems and coping solutions of university students in Taiwan
}

\section{Lin, Mei-Chin}

Graduate Institute of Educational Leadership and Development, Fu Jen Catholic University, Taiwan (041463@mail.fiu.edu.tw)

\section{Pan, Chin-Te}

Center of Teacher Education, Fu Jen Catholic University, Taiwan (017389@mail.fju.edu.tw)

Ching, Gregory S. $\bowtie$

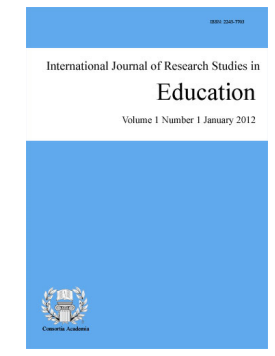

ISSN: 2243-7703 Online ISSN: 2243-7711

OPEN ACCESS

Graduate Institute of Educational Leadership and Development, Fu Jen Catholic University, Taiwan (gregory_ching@yahoo.com; 094478@mail.fju.edu.tw)

\section{Abstract}

University life of today is full of challenges. News of school involved bad incidents has all become too common. In Taiwan, students are also faced with many pressures and problems. Problems such as academic stress, future job uncertainty, and interpersonal relationships are just some of the interrelated complications easily found in universities. To address this issue, the current mixed-method study uses a series of focus group sessions in order to solicit the various issues surrounding students' day to day in-campus life challenges and their corresponding coping strategies. A survey questionnaire was then formulated from the results of the focus group sessions. A total of 123 valid surveys were collected. Data collected were analyzed together with their corresponding demographical backgrounds such as: gender, year level of study, place of living, working or non-working students, and course of study. Results show that the common students' related complications are health problems, future career issues, lessons and examinations, learning difficulties, self-efficacy issues, interpersonal difficulties, time management, and stress causing issues. Statistical analyses were accomplished resulting to significant students' school problems determining background factors such as students' course of study, gender, working or non-working students, and place of living. While no significant differences were found on the common students' coping strategies. Lastly, there seems to be a high correlation between the students' problems and coping strategies within the stress causing issues, suggesting that stress related issues to be the root cause of major complications for university students in Taiwan.

Keywords: college students' problems; coping strategies; students' attitude and behavior; stress; time management 


\section{Common problems and coping solutions of university students in Taiwan}

\section{Introduction}

In most school related violence news report today, issues such as bullying, substance abused, harassments have all become too common (Bidwell, 2014). For the past years, most educators are quite focused with the issues of school bullying (Chapell et al., 2004) and campus violence (Brown, 2013), however, there are many other school related problems that have been persisting, such as students' attitudes and behaviors, frequent absenteeism, non-participation, just to name a few (Bobbitt \& Rohr, 1993). In fact, the number of such non-violence related school problems have actually been increasing (Bidwell, 2014). Hence, there is a serious need for studies regarding such persisting issues within the universities.

Within university life, students of today are not without stress, many actually suffers from both health and emotional issues (Ross, Niebling, \& Heckert, 1999; Townsend et al., 2013). In addition, the advancement and ubiquitous nature of the information highway has also caused a lot of issues, such as internet addiction (Kandell, 1998), which recent researches have shown to have significant correlation with an individuals' depression (Akin \& Iskender, 2011; Orsal, Orsal, Unsal, \& Ozalp, 2013). In addition, many students are also suffering from anxieties that are cause by pressure from their parents (Garrison, 2013), while others have too much pressure in achieving academic success (Staley, 2009). Still, students worry a lot, some because of their low self-esteem and financial problems (Crocker \& Luhtanen, 2003), while others are afraid that they cannot reach their study goals (Malpass, O'Neil, \& Hocevar, 1999). It can be said that the complexity of the problems students faced nowadays is but increasing.

In order to overcome school related challenges, many students seem to go astray. Some student suffers either from alcohol or substance abuse (Simons, Gaher, Correia, Hansen, \& Christopher, 2005; Stea, Hodgins, \& Lambert, 2011; Wechsler \& Nelson, 2001), spends lots of money (Roberts \& Jones, 2001), has some kind of emotional breakdown (Gerdes \& Mallinckrodt, 1994), mental health issues, (Storrie, Ahern, \& Tuckett, 2010), internet addiction (Kandell, 1998), gambling (Stea et al., 2011), excessive eating (Wen, Tchong, \& Ching, 2014) and other health related issues (Grace, 1997; Zaleski, Levey-Thors, \& Schiaffino, 1998), just to name a few. Such negative attitudes and behaviors have been suggested to be the caused for students' low engagement and burnout (Schaufeli, Martínez, Pinto, Salanova, \& Bakker, 2002) and depression (Bayram \& Bilgel, 2008).

Actually, many students have problems with going to college itself (Chang, 1998). In this study, the perceived students' problem-solving ability somehow translates into stress producing situations. A total of 211 college students were surveyed with results suggesting that hope played an important part in overcoming the various stresses. Furthermore, in a study conducted in a US public university, surveys regarding anxiety, depression, and eating habits were given to students. Results show that over half of the students have fall into at least one of the common problematic school issues (Zivin, Eisenberg, Gollust, \& Golberstein, 2009). Such research results further give grounds to the seriousness of the impact of university students' problem.

In Taiwan, university life is also quite challenging (Hsieh, 2010). Students nowadays have too much work and pressure generated from their parents, while some others are unsure of how to manage their future career (Ching \& Chao, 2013). Still some are preoccupied with their part-time job, since prior job experiences leads to future employment (Lin \& Ching, 2014). Many recent studies in Taiwan have been highly focused in students' issues of academic dishonesty (Lin \& Wen, 2006), some even within the graduate students level (Yang, 2012), while some academic dishonesty might be related to some extent with the prevalence of information technology (Ching, 2013; Ching \& Chen, 2011). Furthermore, Cheng (2009) noted that study related stress are caused by physical/mental, school, and emotional factors. In sum, it is quite understandable that as society and technology advances so as with the accompanying related stress increases. Therefore, it is important to become aware of 
what students nowadays are facing, thus be able to provide the proper guidance in handling such stresses.

\subsection{Common university students' coping strategies}

With the various problems faced by the students, many coping strategies have been implemented and are in placed within the schools. For instance, the students' sense of hope is said to have the promise of resiliency. One recent study mentions that the concept of hope can be traced back to the students' elementary school days. Studies have shown that higher parents' life satisfaction can be linked to the students' hope (Hoy, Suldo, \& Mendez, 2013). Such hope can be translated into a strong source of coping when faced with future college related stress (Chang, 1998). More so, the mere concept of belief in a brighter future can also be used as a way of encouraging students (Zhang, 2008). In essence, developing the students' self-efficacy is one of the key component in shaping how students deals with their problems (Chemers, Hu, \& Garcia, 2001).

In addition, universities are also faced with the problems of excessive drinking and other vices. Since, the late 1990s, schools in the US have started to implement various preemptive strategies (Marlatt et al., 1998). Furthermore, schools have also tried to promote various learning strategies in helping students improved their study skills, hence, diminish their academic related problems (Robbins et al., 2004). In addition, the National Survey for Student Engagement series of studies has been able to successfully point out positive strategies in helping educators uplift students' performance. Such activities such as: Level of Academic Challenge, Active and Collaborative Learning, Student-Faculty Interaction, Enriching Educational Experiences, and Supportive Campus Environment all points to the persistent positive engagements of college students (Kuh, 2009; Kuh, Cruce, Shoup, Kinzie, \& Gonyea, 2008). More importantly, there studies noted that students should stay involved with their academic activities, hence, having their academic related issues readily identified.

Besides being able to become involved or engaged in school activities, proper motivation are crucial to helping students stay in school (Struthers, Perry, \& Menec, 2000), while adequate leisure time are also needed to relieved the tension brought about by various academic activities (Shaikh et al., 2004). In sum, many researches have mentioned various coping strategies that are common to college students. However, still the early discovery is crucial in order to provide the proper solutions/interventions to existing problems, while preemptive measures should be in placed to act as a deterrent for future problems.

To address the current college students' problems and coping strategies, the current paper shall focus on the following research questions:

$>\quad$ What are the common students' school problems?

$>\quad$ What are the common students' coping strategies?

$>\quad$ Are there any relationships among the students' demographical background and their school problems and coping strategies?

$>\quad$ Are there any relationships among the students' school problems and coping strategies?

\subsection{Significance of the study}

College students' problems are an important issue. School administrators and teachers are concerned that the students' problems can affect their overall learning development. Hence, it is hoped that the current study is able to provide various important implications not only to the academic community, but for the society as well. More specific concerns are as follows:

$>\quad$ The study is able to open up new ways of understanding why students act the way they are.

$>\quad$ The study also provides various implications regarding the effects of demographical factors towards the students' problems and coping strategies. 
$>$ More importantly, the current study is able to provide insights on the various causes of problems and possible coping strategies that college students of today are using.

\section{Research design}

The study employs a descriptive research paradigm, wherein the conditions that exist and the situations that are ongoing within a certain setting are discussed and analyzed (Cohen, Manion, \& Morrison, 2007). With an objective of determining the various problems that student encounter and coping solution that students exercise, the current study make use of a researchers made survey questionnaire designed from the literature reviews and focus group discussion data.

\subsection{Research process and participants}

The study started in the spring semester of 2013, a series of 4 four group sessions was organized by the researchers with various students volunteer with the goal of soliciting the common problems and coping solutions university students encounter. Afterwards, the summarized results were collated together with various literature reviews through the use of Stenhouse's (1988) categorization style of case data in order to formulate the survey questionnaire. The survey was then administered to 150 volunteer students of a technical vocational university in the northern part of Taiwan. A total of 123 valid survey questionnaires were collected and tabulated. Data analysis was accomplished with the use of the statistical software SPSS version 20.

Table 1, shows the various background demography of the student participants. Data shows that the majority of the students are from the second year with 47 female and 12 male students, while, third year (junior) students accounts to the second highest with 48 female and 4 male students. As for the students' background course study, most students are enrolled in the Applied Foreign Language department with around 36 female and 6 male students. Table 1 also noted the breakdown of students with regards to their course nature, whether they have a part-time job or not, and together with their place of living.

\subsection{Research tool}

The survey is consists of three major sections, besides the basic demographical backgrounds of the students, the remaining parts are the common students' school problems and the common students' coping strategies. The two sections are both consist of similar issues, namely: health problems; these are questions regarding the health issues and emotional problems of the students, career issues; these are items that talks about how students felt when facing the uncertainty of employment after graduation, lessons and examinations; this are items that dealt with the students' concerns toward their grade and examination, learning difficulties; this items talks about the issues about the students' learning, self-efficacy issues; this talks about how students think about themselves and their capabilities, interpersonal difficulties; are items that describe the students' social encounters, time management; deals with how students value time, and stress causing issues; are items that describe the students feeling of anxiety. For the validity of the survey questionnaire, the various factors are computed to be quite valid with Cronbach Alpha reliability ranging from .74 to .95 (see Tables 3 and 5 for the various Alpha reliability values). The survey uses a 5 point Likert scale answering the degree of relationship from $0 \%, 25 \%, 50 \%, 75 \%$, and $100 \%$.

\section{Results and discussions}

The following discussion shall be separated into four sections, namely: 1) Students' school problems; 2) Students' coping strategies; 3) Relationships among the demographical factors and the students' problems and coping strategies, and 4) Relationships among the students' school problems and coping strategies. 
Table 1

Participants' background demography $(N=123)$

\begin{tabular}{|c|c|c|c|c|c|}
\hline \multirow{2}{*}{\multicolumn{2}{|c|}{ Variables }} & \multicolumn{2}{|c|}{ Female } & \multicolumn{2}{|c|}{ Male } \\
\hline & & $n$ & $\%$ & $n$ & $\%$ \\
\hline \multirow[t]{4}{*}{ Year level } & 1 & 4 & 3 & 3 & 2 \\
\hline & 2 & 47 & 38 & 12 & 10 \\
\hline & 3 & 48 & 39 & 4 & 3 \\
\hline & 4 & 3 & 2 & 2 & 2 \\
\hline \multirow[t]{14}{*}{ Course } & Applied Foreign Languages & 36 & 29 & 6 & 5 \\
\hline & Game Science & 30 & 24 & 2 & 2 \\
\hline & Electronic Engineering & 4 & 3 & 3 & 2 \\
\hline & Finance & 13 & 11 & - & - \\
\hline & Information Management & 2 & 2 & - & - \\
\hline & Business Administration & 5 & 4 & - & - \\
\hline & International Business & 7 & 6 & - & - \\
\hline & Information and Network & 1 & 1 & - & - \\
\hline & Creative Industry & 4 & 3 & - & - \\
\hline & Chemical Engineering & - & - & 3 & 2 \\
\hline & Industrial Engineering & - & - & 1 & 1 \\
\hline & Computer Science & - & - & 1 & 1 \\
\hline & Mechanical Engineering & - & - & 3 & 2 \\
\hline & Electrical Engineering & - & - & 2 & 2 \\
\hline \multirow[t]{2}{*}{$\overline{\mathrm{AFL}}$} & AFL students & 36 & 29 & 6 & 5 \\
\hline & Non-AFL students & 66 & 54 & 15 & 12 \\
\hline \multirow[t]{2}{*}{ Work } & Yes & 21 & 17 & 13 & 11 \\
\hline & No & 81 & 66 & 8 & 7 \\
\hline \multirow[t]{3}{*}{ Rent } & Stay with parents & 19 & 15 & 13 & 11 \\
\hline & Rent outside the school & 28 & 23 & 8 & 7 \\
\hline & Dormitory of the school & 55 & 45 & - & - \\
\hline
\end{tabular}

\subsection{Students' school problems}

Table 2 shows the common students' school problems, results show that the highest mean scores are the factor lessons and examinations with a mean of 2.99 denoting a moderate problem. While, the least problematic factor is the self-efficacy issues with a mean of 2.50. The second highest overall mean score is the factor time management with a mean of 2.91 , denoting the issues wherein the students are mostly tardy coming to class. Table 2 also shows that the overall students' problem grand mean of 2.76, which is considered to be moderate. Furthermore, in order to better understand the various students' problem factors and items, Table 3 shows the various results with the highest items in the school problems are the notion of lack of feeling of worthiness (reversely coded*) with a mean of 3.55. While, the lowest item is I cannot control my emotions with a mean of 2.50. Various problems are also noted in Table 3. Worth mentioning are the items that have an unusually high value such as I usually commit errors during tests with a mean of 3.16, I am focused on learning (reversely coded*) with a mean of 3.03 , and I procrastinate a lot with a mean of 3.09 .

Table 2

Overall common students' school problems $(N=123)$

\begin{tabular}{lcccc}
\hline \multicolumn{1}{c}{ Factors } & Mean & SD & Min. & Max. \\
\hline Health problems & 2.64 & 0.88 & 1.00 & 5.00 \\
Career issues & 2.61 & 0.96 & 1.00 & 5.00 \\
Lessons and examinations & $\mathbf{2 . 9 9}$ & 0.94 & 1.00 & 5.00 \\
Learning difficulties & 2.89 & 0.56 & 1.00 & 4.43 \\
Self-efficacy issues & 2.50 & 0.91 & 1.00 & 5.00 \\
Interpersonal difficulties & 2.89 & 0.44 & 1.40 & 3.80 \\
Time management & 2.91 & 0.98 & 1.00 & 5.00 \\
Stress causing issues & 2.63 & 0.88 & 1.00 & 4.25 \\
& & 0.60 & 1.19 & 3.88 \\
\hline
\end{tabular}

Note. Values of interest are in bold face. 
Lin, M.-C., Pan, C.-T., \& Ching, G. S.

Table 3

Common students' school problems $(N=123)$

\begin{tabular}{|c|c|c|}
\hline Factors/Items (Cronbach Alpha reliability) & Mean & $S D$ \\
\hline Health problems (13 items, $\alpha=.95$ ) & 2.64 & 0.88 \\
\hline Too much pressure makes me weak & 2.93 & 1.11 \\
\hline My health is not that good as before & 2.89 & 1.06 \\
\hline I feel tired and weak & 2.82 & 1.12 \\
\hline I am always worried & 2.76 & 1.22 \\
\hline I think something is wrong with my life & 2.73 & 1.16 \\
\hline Everything seems to go bad & 2.69 & 1.16 \\
\hline I am so lazy & 2.63 & 1.12 \\
\hline I fell so hopeless & 2.58 & 1.02 \\
\hline I am afraid I did something wrong & 2.52 & 1.11 \\
\hline I am sad & 2.50 & 1.04 \\
\hline I worry about my emotional health & 2.45 & 1.12 \\
\hline My life is a mess & 2.44 & 1.15 \\
\hline I cannot control my emotions & 2.40 & 1.04 \\
\hline Career issues (6 items, $\alpha=.93$ ) & 2.61 & 0.96 \\
\hline I think my future plans are wrong & 2.85 & 1.12 \\
\hline I don't know what I am capable of doing & 2.76 & 1.18 \\
\hline I am uncertain of my future & 2.75 & 1.11 \\
\hline I don't understand what my strengths are & 2.63 & 1.13 \\
\hline I think I am useless & 2.44 & 1.07 \\
\hline I don't have the motivation to move on & 2.24 & 1.08 \\
\hline Lessons and examinations ( 3 items, $\alpha=.81$ ) & 2.99 & 0.94 \\
\hline I usually commit errors during tests & 3.16 & 1.15 \\
\hline My school lessons are hard and unclear & 2.96 & 1.10 \\
\hline I feel tense during examinations & 2.85 & 1.08 \\
\hline Learning difficulties (7 items, $\alpha=.75$ ) & 2.89 & 0.56 \\
\hline I am focused on learning* & 3.03 & 0.94 \\
\hline I am motivated to learn* & 3.02 & 0.95 \\
\hline I just cannot concentrate & 2.88 & 0.92 \\
\hline My grades are not that good & 2.88 & 1.03 \\
\hline My learning methods are wrong & 2.85 & 1.02 \\
\hline My memories are weak & 2.80 & 0.96 \\
\hline My classmates are better than me & 2.75 & 1.05 \\
\hline Self-efficacy issues (7 items, $\alpha=.92$ ) & 2.50 & 0.91 \\
\hline I am unsure of myself & 2.56 & 1.13 \\
\hline I look down on myself & 2.55 & 1.10 \\
\hline I always ashamed of myself & 2.54 & 1.11 \\
\hline I cannot express myself & 2.53 & 1.14 \\
\hline I feel empty & 2.47 & 1.09 \\
\hline I am not good looking & 2.46 & 1.06 \\
\hline I don't understand myself & 2.44 & 1.11 \\
\hline Interpersonal difficulties ( 5 items, $\alpha=.85$ ) & 2.89 & 0.44 \\
\hline I am a worthwhile person* & 3.55 & 0.94 \\
\hline I had a bad experience with friends & 3.19 & 1.07 \\
\hline I am full of vigor* & 2.64 & 0.92 \\
\hline I am satisfy with my social life* & 2.59 & 0.89 \\
\hline I am a happy person* & 2.50 & 1.00 \\
\hline Time management ( 3 items, $\alpha=.82$ ) & 2.91 & 0.98 \\
\hline I procrastinate a lot & 3.09 & 1.17 \\
\hline I don't know how to manage my time & 3.07 & 1.07 \\
\hline I am always late in class & 2.57 & 1.20 \\
\hline Stress causing issues ( 4 items, $\alpha=.81$ ) & 2.63 & 0.88 \\
\hline I am always worried at someone & 2.84 & 1.11 \\
\hline I am uneasy all the time & 2.69 & 1.11 \\
\hline My life is full of tension & 2.54 & 1.07 \\
\hline My family gives me pressure & 2.44 & 1.15 \\
\hline
\end{tabular}

Note. $*$ items reverse coded. Factor mean values are in bold face. Overall $\alpha=.95$ 


\subsection{Students' coping strategies}

For the coping strategies, Table 4 shows the various practices that students mostly use. Results show the highest of the coping factor stress coping issues with a mean of 3.76. This is quite encouraging that students are able to handle their anxiety and pressures. The least practiced strategies are the self-efficacy issues with a mean of 3.51. Looking in a wider picture, the overall coping mean scores is 3.62, denoting a high or frequent practice of coping strategies. These results signify that students are quite conscious with their own situation and are able to apply the right coping strategies. In addition, all of mean scores are quite high, signifying the frequent practice of the various coping strategies.

For the various items of the coping strategies, Table 5 shows the tabulated results. Data shows that the highest item is take care of oneself with a mean of 3.91, while the lowest item is go to bed and wake up early with a mean of 3.31. Hence, the various items have mean scores of moderately high to high value.

\section{Table 4}

Overall common students' coping strategies $(N=123)$

\begin{tabular}{|c|c|c|c|c|}
\hline Factors & Mean & $S D$ & Min. & Max. \\
\hline Health problems & 3.63 & 0.65 & 1.50 & 5.00 \\
\hline Career issues & 3.55 & 0.80 & 1.00 & 5.00 \\
\hline Lessons and examinations & 3.62 & 0.69 & 1.00 & 5.00 \\
\hline Learning difficulties & 3.64 & 0.68 & 1.00 & 5.00 \\
\hline Self-efficacy issues & 3.51 & 0.77 & 1.00 & 5.00 \\
\hline Interpersonal difficulties & 3.65 & 0.76 & 1.00 & 5.00 \\
\hline Time management & 3.60 & 0.75 & 1.67 & 5.00 \\
\hline Stress coping issues & 3.76 & 0.58 & 2.50 & 5.00 \\
\hline Total solutions & 3.62 & 0.51 & 2.13 & 5.00 \\
\hline
\end{tabular}

Note. Values of interest are in bold face.

\subsection{Relationships among the demographical factors and the students' problems and coping strategies}

For the relationships among the demographical factors and the students' problems and coping strategies, t-test results show that there are no significant differences in all the factors (problems and coping strategies) with regards to the students' year level. This means the problems and coping strategies are not limited to the students' year of study. In addition, results also show that there are no significant differences in the coping strategies among the Applied Foreign Language (AFL) and non-AFL students; however, there are significant differences in the students' problem among the AFL and non-AFL students.

Table 6 shows that AFL students tend to have higher problems as compared to students of other department. Results are as follows: Overall common students' problems $\mathrm{t}=2.998, p=.003$ (AFL Mean=2.97 $\mathrm{SD}=0.534$, non-AFL Mean=2.65 SD=0.598), Health problems $\mathrm{t}=3.754, p=.000$ (AFL Mean=3.04 SD=0.923, non-AFL Mean=2.44 SD=0.794), Self-efficacy issues $\mathrm{t}=2.365, p=.020$ (AFL Mean=2.77 SD=0.809, non-AFL Mean=2.37 $\mathrm{SD}=0.929$ ), Time management $\mathrm{t}=2.318, p=.022$ (AFL Mean=3.19 SD=1.018, non-AFL Mean=2.77 SD=0.936), and Stress causing issues $\mathrm{t}=2.582, p=.011$ (AFL Mean=2.90 SD=0.783, non-AFL Mean=2.48 SD=0.900).

In addition, results also shows that there are no significant gender differences in the coping strategies of the student participants; however, there are significant gender differences in the common students' problem. Table 7 shows that male students have more problems than their female student counterparts. More importantly, the differences are with the similar factors as of the previous mentioned AFL and non-AFL students. Specific results are as follows: Overall common students' problems $\mathrm{t}=3.109, p=.002$ (Female Mean=2.69 SD=0.595, Male Mean=3.09 $\mathrm{SD}=0.486$ ), Health problems $\mathrm{t}=1.800, p=.074$ (Female Mean=2.58 SD=0.870, Male Mean=2.95 $\mathrm{SD}=0.909$ ), Self-efficacy issues $\mathrm{t}=2.517, p=.013$ (Female Mean=2.41 SD=0.900, Male Mean=2.95 SD=0.822), Time management $\mathrm{t}=4.502, p=.000$ (Female Mean=2.78 SD=0.988, Male Mean=3.56 SD=0.653), and Stress coping issues $\mathrm{t}=2.897, p=.004$ (Female Mean=2.52 $\mathrm{SD}=0.861$, Male Mean=3.12 $\mathrm{SD}=0.835$ ). Effect sizes for 
Lin, M.-C., Pan, C.-T., \& Ching, G. S.

Tables 6 and 7 were computed with the use of the Eta squared formula suggesting small (.01 to .05) to moderate (.06 to .13) effect sizes (Cohen, 1988).

\section{Table 5}

Common students' coping practices $(N=123)$

\begin{tabular}{|c|c|c|}
\hline Factors/Items (Alpha reliability) & Mean & $S D$ \\
\hline Health problems $(6$ items, Alpha $=.84)$ & 3.63 & 0.65 \\
\hline Listen to music & 3.85 & 1.06 \\
\hline Enjoy nature & 3.80 & 1.06 \\
\hline Talk to friends & 3.66 & 0.90 \\
\hline Consumes alcohol* & 3.66 & 1.32 \\
\hline Eat a lot* & 3.49 & 1.15 \\
\hline Go to bed and wake up early & 3.31 & 0.96 \\
\hline Career issues $(5$ items, Alpha $=.86)$ & 3.55 & 0.80 \\
\hline Try to invest on own competencies & 3.67 & 0.98 \\
\hline Look for a part-time job & 3.62 & 0.96 \\
\hline Talk to an adult (teacher/parents) & 3.54 & 0.95 \\
\hline Attend career seminars & 3.46 & 1.02 \\
\hline Take a career examination/tests & 3.45 & 1.05 \\
\hline Lessons and examinations $(5$ items, Alpha $=.85)$ & 3.62 & 0.69 \\
\hline Ask classmates for help & 3.70 & 0.76 \\
\hline Read before coming to class & 3.68 & 0.86 \\
\hline Check your answers twice & 3.67 & 0.84 \\
\hline Prepare early during examinations & 3.58 & 0.92 \\
\hline Ask for teacher assistance & 3.50 & 0.94 \\
\hline Learning difficulties $(5$ items, Alpha $=.80)$ & 3.64 & 0.68 \\
\hline Listen in class & 3.74 & 0.90 \\
\hline Study with classmates & 3.67 & 0.92 \\
\hline Study hard & 3.60 & 0.89 \\
\hline Make a study plan & 3.59 & 0.94 \\
\hline Talk to teachers & 3.59 & 0.91 \\
\hline Self-efficacy issues $(4$ items, Alpha $=.79)$ & 3.51 & 0.77 \\
\hline Try to find enjoyment in doing new things & 3.76 & 0.95 \\
\hline Attend some self-help classes & 3.48 & 1.04 \\
\hline Talk to a school counselor & 3.42 & 0.99 \\
\hline Try to dress up and feel good about oneself & 3.39 & 0.93 \\
\hline Interpersonal difficulties (4 items, Alpha $=.81$ ) & 3.65 & 0.76 \\
\hline Join a school club & 3.76 & 0.93 \\
\hline Make new friends & 3.75 & 0.87 \\
\hline Join school activities & 3.62 & 1.00 \\
\hline Join the student council & 3.49 & 1.00 \\
\hline Time management $(3$ items, Alpha $=.79)$ & 3.60 & 0.75 \\
\hline Make a schedule and abide by it & 3.68 & 0.89 \\
\hline Setup an alarm as a reminder & 3.67 & 0.87 \\
\hline Push through schedules already set & 3.44 & 0.91 \\
\hline Stress coping issues $(6$ items, Alpha $=.74)$ & 3.76 & 0.58 \\
\hline Take care of oneself & 3.91 & 0.81 \\
\hline Practice emotional control & 3.89 & 0.78 \\
\hline Control my emotions & 3.83 & 0.86 \\
\hline Talk more with my parents & 3.76 & 0.91 \\
\hline Slow down & 3.76 & 0.86 \\
\hline Keeping busy & 3.39 & 1.01 \\
\hline
\end{tabular}

Note. $*$ items reverse coded. Factor mean values are in bold face. Overall $\alpha=.93$ 
Table 6

T-test results of non-AFL/AFL and common students' problems $(N=123)$

\begin{tabular}{|c|c|c|c|c|c|c|}
\hline \multirow{2}{*}{ Factors } & & \multicolumn{2}{|c|}{ Course } & \multirow[b]{2}{*}{$t$} & \multirow[b]{2}{*}{$p$} & \multirow[b]{2}{*}{$E_{t a}{ }^{2}$} \\
\hline & & non-AFL $(n=81)$ & AFL $(n=42)$ & & & \\
\hline \multirow[t]{2}{*}{ Overall students' problem } & Mean & 2.65 & 2.97 & 2.998 & .003 & .07 \\
\hline & $S D$ & 0.60 & 0.53 & & & \\
\hline \multirow[t]{2}{*}{ Health problems } & Mean & 2.44 & 3.04 & 3.754 & .000 & .01 \\
\hline & $S D$ & 0.79 & 0.92 & & & \\
\hline \multirow[t]{2}{*}{ Self-efficacy issues } & Mean & 2.37 & 2.77 & 2.365 & .020 & .04 \\
\hline & $S D$ & 0.93 & 0.81 & & & \\
\hline \multirow[t]{2}{*}{ Time management } & Mean & 2.77 & 3.19 & 2.318 & .022 & .04 \\
\hline & $S D$ & 0.94 & 1.02 & & & \\
\hline \multirow[t]{2}{*}{ Stress causing issues } & Mean & 2.48 & 2.90 & 2.582 & .011 & .05 \\
\hline & $S D$ & 0.90 & 0.78 & & & \\
\hline
\end{tabular}

Note. Values of interest are in bold face.

Table 7

T-test results of gender and common students' problems $(N=123)$

\begin{tabular}{|c|c|c|c|c|c|c|}
\hline \multirow{2}{*}{ Factors } & & \multicolumn{2}{|c|}{ Gender } & \multirow[b]{2}{*}{$t$} & \multirow[b]{2}{*}{$p$} & \multirow[b]{2}{*}{$E t a^{2}$} \\
\hline & & female $(n=102)$ & male $(n=21)$ & & & \\
\hline \multirow[t]{2}{*}{ Overall students' problem } & Mean & 2.69 & 3.09 & 3.109 & .002 & .07 \\
\hline & $S D$ & 0.60 & 0.49 & & & \\
\hline \multirow[t]{2}{*}{ Health problems } & Mean & 2.58 & 2.95 & 1.800 & .074 & .03 \\
\hline & $S D$ & 0.87 & 0.91 & & & \\
\hline \multirow[t]{2}{*}{ Self-efficacy issues } & Mean & 2.41 & 2.95 & 2.517 & .013 & .05 \\
\hline & $S D$ & 0.90 & 0.82 & & & \\
\hline \multirow[t]{2}{*}{ Time management } & Mean & 2.78 & 3.56 & 4.502 & .000 & .14 \\
\hline & $S D$ & 0.99 & 0.65 & & & \\
\hline \multirow[t]{2}{*}{ Stress causing issues } & Mean & 2.52 & 3.12 & 2.897 & .004 & .06 \\
\hline & $S D$ & 0.86 & 0.84 & & & \\
\hline
\end{tabular}

Note. Values of interest are in bold face.

As for the impact of students living in the dormitory, outside the school, and with their parents, Analysis of Variance (ANOVA) was computed. Table 8 shows the summary of the ANOVA results. Results show that the factors Health problems $(\mathrm{F}=9.350, p=.000)$, Self-efficacy issues $(\mathrm{F}=6.595, p=.002)$, Time management $(\mathrm{F}=6.859$, $p=.002)$, Stress causing issues $(\mathrm{F}=7.089, p=.001)$, and Overall problems $(\mathrm{F}=8.461, p=.000)$ have significant differences with their places of living whether at home, outside the school, or within the school's dorm. In addition, post hoc analysis results (shaded values in bold) shows that students living at home tends to scored higher in the various school problem factors as compared to their peers staying outside the school and within the school's dorm. These findings are quite interesting and valid a follow-up study in the future. Effect sizes for Table 8 were also computed with the use of the Eta squared formula suggesting moderate (.06 to .13) effect sizes (Cohen, 1988).

Lastly, t-test results in Table 9 shows that there are significant differences in the students' problem among the students who are working and not working in terms of the factor time management $\mathrm{t}=2.380 p=.019$ (not working Mean=2.78 SD=1.000, working Mean=3.25 SD=0.858) with Eta squared value of .40; denoting a small effect size. This result is quite acceptable since the working students are always in need of time to study; hence, they have many problems in time management. This result provides an interesting proof that working students need to be guided regularly. Students work with various reasons in mind, however, most students would want to have enough work experiences that might translate to a better future career (Lin \& Ching, 2014). Therefore, educators should be sensitive to their students' attitude, the more with students who are often tardy. 
Lin, M.-C., Pan, C.-T., \& Ching, G. S.

\section{Table 8}

ANOVA results of place of living and common students' problems $(N=123)$

\begin{tabular}{|c|c|c|c|c|c|c|c|}
\hline Factors & $n$ & $\begin{array}{c}\text { Home } \\
32\end{array}$ & $\begin{array}{c}\text { Outside } \\
36\end{array}$ & $\begin{array}{c}\text { Dorm } \\
55\end{array}$ & $F$ & $p$ & $E_{t a}{ }^{2}$ \\
\hline \multirow[t]{2}{*}{ Health problems } & Mean & 3.11 & 2.71 & 2.32 & 9.350 & .000 & .13 \\
\hline & $S D$ & 0.85 & 0.90 & 0.77 & & & \\
\hline \multirow[t]{2}{*}{ Home } & $M D$ & & 0.40 & 0.79 & & & \\
\hline & $p$ & & .124 & .000 & & & \\
\hline \multirow[t]{2}{*}{ Outside the school } & $M D$ & & & 0.39 & & & \\
\hline & $p$ & & & .074 & & & \\
\hline \multirow[t]{2}{*}{ Self-efficacy issues } & Mean & 2.87 & 2.64 & 2.20 & 6.595 & .002 & .10 \\
\hline & $S D$ & 0.72 & 0.88 & 0.94 & & & \\
\hline \multirow[t]{2}{*}{ Home } & $M D$ & & 0.23 & 0.67 & & & \\
\hline & $p$ & & .530 & .002 & & & \\
\hline \multirow[t]{2}{*}{ Outside the school } & $M D$ & & & 0.44 & & & \\
\hline & $p$ & & & .052 & & & \\
\hline \multirow[t]{2}{*}{ Time management } & Mean & 3.23 & 3.16 & 2.56 & 6.859 & .002 & .10 \\
\hline & $S D$ & 0.88 & 0.99 & 0.94 & & & \\
\hline \multirow[t]{2}{*}{ Home } & $M D$ & & 0.07 & 0.67 & & & \\
\hline & $p$ & & .947 & .005 & & & \\
\hline \multirow[t]{2}{*}{ Outside the school } & $M D$ & & & 0.59 & & & \\
\hline & $p$ & & & .010 & & & \\
\hline \multirow[t]{2}{*}{ Stress causing issues } & Mean & 3.06 & 2.65 & 2.36 & 7.089 & .001 & .11 \\
\hline & $S D$ & 0.82 & 0.79 & 0.88 & & & \\
\hline \multirow[t]{2}{*}{ Home } & $M D$ & & 0.42 & 0.70 & & & \\
\hline & $p$ & & .107 & .001 & & & \\
\hline \multirow[t]{2}{*}{ Outside the school } & $M D$ & & & 0.29 & & & \\
\hline & $p$ & & & .254 & & & \\
\hline \multirow[t]{2}{*}{ Overall problems } & Mean & 3.03 & 2.86 & 2.54 & 8.461 & .000 & .12 \\
\hline & $S D$ & 0.45 & 0.55 & 0.62 & & & \\
\hline \multirow[t]{2}{*}{ Home } & $M D$ & & 0.17 & 0.49 & & & \\
\hline & $p$ & & .449 & .000 & & & \\
\hline \multirow[t]{2}{*}{ Outside the school } & $M D$ & & & 0.32 & & & \\
\hline & $p$ & & & .024 & & & \\
\hline
\end{tabular}

Note. Significant difference mean scores are shaded.

Table 9

T-test results of whether working or not and common students' problems $(N=123)$

\begin{tabular}{ccccccc}
\hline \multirow{2}{*}{ Factor } & & \multicolumn{3}{c}{ Work } & & \multicolumn{2}{c}{$E^{2}$} \\
\cline { 2 - 6 } & & no $(n=89)$ & yes $(n=34)$ & & $p$ & $E^{2}$ \\
\hline \multirow{2}{*}{ Time management } & Mean & 2.78 & $\mathbf{3 . 2 5}$ & 2.380 & .019 & .04 \\
& SD & 1.00 & 0.86 & & & \\
\hline
\end{tabular}

Note. Values of interest are in bold face.

\subsection{Relationships among the students' school problems and coping strategies}

Table 10 shows the relationship between common students' school problems factors. Results show that the factors are quite related to each other (denoted by the bold values) except the interpersonal difficulties factor. This suggests that the students' problems are also much related to each other. In addition, the factor stress causing issues (shaded values in bold) seem to be quite correlated to the rest of the factors. This result suggests that the stress causing issues that students are suffering might be the root cause of their problems. In other words, as the mean scores of the stress causing issues increases, the other mean scores of the school problem factors also increases. 


\section{Table 10}

Relationship between common students' school problems $(N=123)$

\begin{tabular}{|c|c|c|c|c|c|c|c|c|c|c|}
\hline \multirow{2}{*}{$\frac{\text { Factors }}{\text { Health problems (1) }}$} & & $(1)$ & $(2)$ & $(3)$ & (4) & $(5)$ & $(6)$ & $(7)$ & $(8)$ & (9) \\
\hline & $r$ & 1 & & & & & & & & \\
\hline \multirow{3}{*}{ Career issues (2) } & $p$ & & & & & & & & & \\
\hline & $r$ & .70 & 1 & & & & & & & \\
\hline & $p$ & .000 & & & & & & & & \\
\hline \multirow[t]{2}{*}{ Lessons and examinations (3) } & $r$ & .59 & .47 & 1 & & & & & & \\
\hline & $p$ & .000 & .000 & & & & & & & \\
\hline \multirow[t]{2}{*}{ Learning difficulties (4) } & $r$ & .53 & .47 & .48 & 1 & & & & & \\
\hline & $p$ & .000 & .000 & .000 & & & & & & \\
\hline \multirow[t]{2}{*}{ Self-efficacy issues (5) } & $r$ & .69 & .66 & .45 & .55 & 1 & & & & \\
\hline & $p$ & .000 & .000 & .000 & .000 & & & & & \\
\hline \multirow[t]{2}{*}{ Interpersonal difficulties (6) } & $r$ & .20 & .06 & .09 & .28 & .25 & 1 & & & \\
\hline & $p$ & .024 & .532 & .300 & .002 & .006 & & & & \\
\hline \multirow[t]{2}{*}{ Time management (7) } & $r$ & .31 & .28 & .37 & .43 & .41 & .12 & 1 & & \\
\hline & $p$ & .000 & .002 & .000 & .000 & .000 & .178 & & & \\
\hline \multirow{2}{*}{ Stress causing issues ( 8 ) } & $r$ & .66 & .53 & .46 & .50 & .68 & .28 & .35 & 1 & \\
\hline & $p$ & .000 & .000 & .000 & .000 & .000 & .002 & .000 & & \\
\hline \multirow[t]{2}{*}{ Overall school problem (9) } & $r$ & .84 & .77 & .72 & .72 & .84 & .32 & .60 & .80 & 1 \\
\hline & $p$ & .000 & .000 & .000 & .000 & .000 & .000 & .000 & .000 & \\
\hline
\end{tabular}

Note. Significant correlations are shaded.

Similarly, Table 11 shows the relationship between common students' coping strategies factors. Results show that the factors are much correlated with each other (denoted by the bold values) except some factors of time management and interpersonal difficulties. These suggest that students who are able to cope in one of the situations would tend to cope with the others. In addition, similar to the students' problems, the factor stress coping issues (shaded values in bold) also seem to affect the rest of the coping strategies. With this in mind, the study suggests that if the students are able to pursue their stress coping issues, the rest of their problems would be minimized.

Table 11

Relationship between common students' coping strategies $(N=123)$

\begin{tabular}{|c|c|c|c|c|c|c|c|c|c|c|}
\hline \multirow{2}{*}{$\frac{\text { Factors }}{\text { Health problems (1) }}$} & & $(1)$ & $(2)$ & (3) & (4) & $(5)$ & $(6)$ & (7) & $(8)$ & $(9)$ \\
\hline & $r$ & 1 & & & & & & & & \\
\hline \multirow{3}{*}{ Career issues (2) } & $p$ & & & & & & & & & \\
\hline & $r$ & .32 & 1 & & & & & & & \\
\hline & $p$ & .000 & & & & & & & & \\
\hline \multirow[t]{2}{*}{ Lesson and examination (3) } & $r$ & .35 & .66 & 1 & & & & & & \\
\hline & $p$ & .000 & .000 & & & & & & & \\
\hline \multirow[t]{2}{*}{ Learning difficulties (4) } & $r$ & .36 & .54 & .77 & 1 & & & & & \\
\hline & $p$ & .000 & .000 & .000 & & & & & & \\
\hline \multirow[t]{2}{*}{ Self-efficacy issues (5) } & $r$ & .20 & .49 & .47 & .56 & 1 & & & & \\
\hline & $p$ & .028 & .000 & .000 & .000 & & & & & \\
\hline \multirow[t]{2}{*}{ Interpersonal difficulties (6) } & $r$ & .17 & .39 & .43 & .50 & .67 & 1 & & & \\
\hline & $p$ & .064 & .000 & .000 & .000 & .000 & & & & \\
\hline \multirow[t]{2}{*}{ Time management (7) } & $r$ & .13 & .29 & .38 & .50 & .55 & .51 & 1 & & \\
\hline & $p$ & .159 & .001 & .000 & .000 & .000 & .000 & & & \\
\hline \multirow[t]{2}{*}{ Stress coping issues ( 8 ) } & $r$ & .25 & .38 & .55 & .57 & .48 & .47 & .61 & 1 & \\
\hline & $p$ & .005 & .000 & .000 & .000 & .000 & .000 & .000 & & \\
\hline \multirow[t]{2}{*}{ Students' coping strategies (9) } & $r$ & .47 & .72 & .80 & .83 & .78 & .73 & .69 & .73 & 1 \\
\hline & $p$ & .000 & .000 & .000 & .000 & .000 & .000 & .000 & .000 & \\
\hline
\end{tabular}

To determine the relationship between the overall problems and coping strategies, correlation test was accomplished. Result shows that they are significantly negative correlated with a Pearson's $r$ value of -.180 , 
$p=.047$. Meaning when a student practices the coping strategies, these would successfully lessen their in school problems. To further determine relationships of the stress related issues with the other factors, regression analyses were accomplished. Stepwise regression was used to predict which factor or factors to add or drop in the estimates (Warner, 2008).

Stepwise regression analysis for the stress causing issues resulted in having two predictors; self-efficacy issues (beta $=.425$; moderate effect) and health related issues (beta $=.377$; moderate effect) to be statistically significant with $\mathrm{R}=.737, \mathrm{R}^{2}=.543, \mathrm{~F}(2,119)=70.76, p<.000$, meaning the two factors are able to account for $54.3 \%$ of the variance in the stress causing issues. In addition, the stepwise regression analysis for the stress coping issues also resulted in having two predictors; time management (beta $=.466$; moderate effect) and lessons and examinations (beta $=.374$; moderate effect) to be statistically significant with $\mathrm{R}=.699, \mathrm{R}^{2}=.489, \mathrm{~F}(2,120$ ) $=57.40, p<.000$, meaning the two factors are able to account for $48.9 \%$ of the variances in the stress coping issues. These results fairly suggest that the inherent stress causing factors are an individual's self-efficacy and health related issues. Similarly, the stress coping factors are quite dependent on having an effective time management scheme and successful coping with one's school lessons and exams. Further studies are recommended in order to better determine the underpinning issues behind these findings.

\section{Conclusions}

The major objective of this study is to determine the common students' school problems and their corresponding coping strategies, while also understanding the effects of their demographical background. Results show that the common issues are health problems, career issues, lessons and examinations, learning difficulties, self-efficacy issues, interpersonal difficulties, time management, and stress causing issues. Statistical analyses were accomplished resulting to significant determining factors such as students' course of study, gender, working or non-working students, and place of living with the common students' school problems. While no significant difference within the common students' coping strategies. Lastly, there seems to be a high correlation between the problems and coping strategies within the stress causing issues, suggesting that these stress causing issues as the root cause of major problems within the students. It is suggested that schools should have a system of early discovery mechanism, which is crucial in order to provide solutions/interventions to existing problems, while preemptive measures should also be in placed to act as a deterrent for future problems.

NOTE: Some parts of the earlier version of this paper has been accepted and scheduled to be presented at the upcoming 2015 Hawaii International Conference on Education in Honolulu, Hawaii on January 5-8, 2015.

\section{References}

Akin, A., \& Iskender, M. (2011). Internet addiction and depression, anxiety and stress. International Online Journal of Educational Sciences, 3(1), 138-148.

Bayram, N., \& Bilgel, N. (2008). The prevalence and socio-demographic correlations of depression, anxiety and stress among a group of university students. Social Psychiatric Epidemiology, 43(8), 667-672. http://dx.doi.org/10.1007/s00127-008-0345-x

Bidwell, A. (2014). Report: School crime and violence rise. Retrieved from http://www.usnews.com/news/articles/2014/06/10/incidents-of-school-crime-and-violence-on-the-rise-f or-students-and-teachers

Bobbitt, S. A., \& Rohr, C. L. (1993). What are the most serious problems in schools? Retrieved from http://nces.ed.gov/pubs93/web/93149.asp

Brown, W. R. (2013). A comparative case study analysis of campus violence prevention plans at three Illinois higher education institutions. Unpublished Doctoral dissertation, Southern Illinois University.

Chang, E. C. (1998). Hope, problem-solving ability, and coping in a college student population: Some implications for theory and practice. Journal of Clinical Psychology, 54(7), 953-962. http://dx.doi.org/10.1002/(SICI)1097-4679(199811)54:7<953::AID-JCLP9>3.0.CO;2-F 
Common problems and coping solutions of university students in Taiwan

Chapell, M., Casey, D., De la Cruz, C., Ferrell, J., Forman, J., Lipkin, R., et al. (2004). Bullying in college by students and teachers. Adolescence, 39(153), 53-64.

Chemers, M. M., Hu, L.-t., \& Garcia, B. F. (2001). Academic self-efficacy and first year college student performance and adjustment. Journal of Educational Psychology, 93(1), 55-64. http://dx.doi.org/10.1037/0022-0663.93.1.55

Cheng, K.-W. (2009). A study of stress sources among college students in Taiwan [Electronic Version]. Journal of Academic and Business Ethics, 9, from http://www.aabri.com/manuscripts/10471.pdf

Ching, G. S. (2013). Computer science students and their sense of academic integrity. International Journal of Information and Education Technology, 3(1), 83-87. http://dx.doi.org/10.7763/IJIET.2013.V3.239

Ching, G. S., \& Chao, P.-C. (2013). Career inclination of university students in Taiwan. In Advances in education research: Social Science and Education (vol. 46, pp. 72-77). Newmark, DE: Information Engineering Research Institute.

Ching, G. S., \& Chen, Y.-L. (2011). Information technology and the factors that affect college cheating in students. In M. Koehler \& P. Mishra (Eds.), Proceedings of society for information technology and teacher education international conference (pp. 1286-1292). Chesapeake, VA: AACE.

Cohen, J. (1988). Statistical power analysis for the behavioral sciences. Hillsdale, NJ: Erlbaum.

Cohen, L., Manion, L., \& Morrison, K. (2007). Research methods in education. New York: Routledge.

Crocker, J., \& Luhtanen, R. K. (2003). Level of self-esteem and contingencies of self-worth: Unique effects on academic, social, and financial problems in college students. Personality and Social Psychology Bulletin, 29(6), 701-712. http://dx.doi.org/10.1177/0146167203029006003

Garrison, D. M. (2013). A phenomenological study of parental involvement and the undergraduate college student experience. Unpublished Masteral thesis, Drexel University.

Gerdes, H., \& Mallinckrodt, B. (1994). Emotional, social, and academic adjustment of college students: A longitudinal study of retention. Journal of Counseling \& Development, 72(3), 281-288. http://dx.doi.org/10.1002/j.1556-6676.1994.tb00935.x

Grace, T. W. (1997). Health problems of college students. Journal of American College Health, 45(6), $243-251$. http://dx.doi.org/10.1080/07448481.1997.9936894

Hoy, B., Suldo, S., \& Mendez, L. (2013). Links between parents' and children's levels of gratitude, life satisfaction, and hope. Journal of Happiness Studies, 14(4), 1343-1361. http://dx.doi.org/10.1007/s10902-012-9386-7

Hsieh, M.-C. (2010). Education in Taiwan is too much and too hard. Retrieved October 25, 2014, from http://www.taipeitimes.com/News/editorials/archives/2010/03/01/2003466920/1

Kandell, J. J. (1998). Internet addiction on campus: The vulnerability of college students. CyberPsychology and Behavior, 1(1), 11-17. http://dx.doi.org/10.1089/cpb.1998.1.11

Kuh, G. D. (2009). The national survey of student engagement: Conceptual and empirical foundations. New Directions for Institutional Research, 141, 5-21. http://dx.doi.org/10.1002/ir.283

Kuh, G. D., Cruce, T., Shoup, R., Kinzie, J., \& Gonyea, R. (2008). Unmasking the effects of student engagement on first-year college grades and persistence. The Journal of Higher Education, 79(5), 540-563. http://dx.doi.org/10.1353/jhe.0.0019

Lin, C.-H. S., \& Wen, L.-Y. M. (2006). Academic dishonesty in higher education: A nationwide study in Taiwan. Higher Education, 54(1), 85-87. http://dx.doi.org/10.1007/s10734-006-9047-z

Lin, M.-C., \& Ching, G. S. (2014). College student' employability: Implications of part-time job during college years. In H. Chen (Ed.), Advances in public, environmental and occupational health (vol. 4, pp. 101-106). Singapore: Singapore Management and Sports Science Institute

Malpass, J. R., O'Neil, H. F., \& Hocevar, D. (1999). Self-regulation, goal orientation, self-efficacy, worry, and high-stakes math achievement for mathematically gifted high school students. Roeper Review, 21(4), 281-288. http://dx.doi.org/10.1080/02783199909553976

Marlatt, G. A., Baer, J. S., Kivlahan, D. R., Dimeff, L. A., Larimer, M. E., Quigley, L. A., et al. (1998). Screening and brief intervention for high-risk college student drinkers: Results from a 2-year follow-up assessment. Journal of Consulting and Clinical Psychology, 66(4), 604-615. http://dx.doi.org/10.1037/0022-006X.66.4.604

Orsal, O., Orsal, O., Unsal, A., \& Ozalp, S. S. (2013). Evaluation of internet addiction and depression among university students. Procedia - Social and Behavioral Sciences, 82, 445-454. http://dx.doi.org/10.1016/j.sbspro.2013.06.291

Robbins, S. B., Lauver, K., Le, H., Davis, D., Langley, R., \& Carlstrom, A. (2004). Do psychosocial and study skill factors predict college outcomes? A meta-analysis. Psychological Bulletin, 130(2), 261-288. http://dx.doi.org/10.1037/0033-2909.130.2.261

Roberts, J. A., \& Jones, E. L. I. (2001). Money attitudes, credit card use, and compulsive buying among 
Lin, M.-C., Pan, C.-T., \& Ching, G. S.

American college students. Journal of Consumer Affairs, 35(2), 213-240.

http://dx.doi.org/10.1111/j.1745-6606.2001.tb00111.x

Ross, S. E., Niebling, B. C., \& Heckert, T. M. (1999). Sources of stress among college students. College Student Journal, 33(2), 312-317.

Schaufeli, W. B., Martínez, I. M., Pinto, A. M., Salanova, M., \& Bakker, A. B. (2002). Burnout and engagement in university students: A cross-national study. Journal of Cross-Cultural Psychology, 33(5), 464-481. http://dx.doi.org/10.1177/0022022102033005003

Shaikh, B. T., Kahloon, A., Kazmi, M., Khalid, H., Nawaz, K., Khan, N. A., et al. (2004). Students, stress and coping strategies: A case of Pakistani medical school. Education for Health, 17(3), 346-353. http://dx.doi.org/10.1080/13576280400002585

Simons, J. S., Gaher, R. M., Correia, C. J., Hansen, C. L., \& Christopher, M. S. (2005). An affective-motivational model of marijuana and alcohol problems among college students. Psychology of Addictive Behaviors, 19(3), 326-334. http://dx.doi.org/10.1037/0893-164X.19.3.326

Staley, C. (2009). Focus on college success (4th ed.). Boston, MA: Cenage learning.

Stea, J. N., Hodgins, D. C., \& Lambert, M. J. (2011). Relations between delay discounting and low to moderate gambling, cannabis, and alcohol problems among university students. Behavioral Processes, 88(3), 202-205. http://dx.doi.org/10.1016/j.beproc.2011.09.002

Stenhouse, L. (1988). Case study methods. In J. P. Keeves (Ed.), Educational research, methodology, and measurement: An international handbook (pp. 49-53). Sydney: Pergamon Press.

Storrie, K., Ahern, K., \& Tuckett, A. (2010). A systematic review: Students with mental health problems - A growing problem. International Journal of Nursing Practice, 16(1), 1-6. http://dx.doi.org/10.1111/j.1440-172X.2009.01813.x

Struthers, C. W., Perry, R., \& Menec, V. (2000). An examination of the relationship among academic stress, coping, motivation, and performance in college. Research in Higher Education, 41(5), 581-592. http://dx.doi.org/10.1023/A:1007094931292

Townsend, J., Hsieh, P.-C., Puymbroeck, M. V., Johnston, J., Gassman, R., Agley, J., et al. (2013). Sense of coherence, perceived stress and health related quality of life in college students. Illuminare: A Student Journal in Recreation, Parks, and Leisure Studies, 11(1), 69-74.

Warner, R. M. (2008). Applied statistics: From bivariate through multivariate techniques. Thousand Oaks, CA: Sage.

Wechsler, H., \& Nelson, T. F. (2001). Binge drinking and the American college students: What's five drinks? Psychology of Addictive Behaviors, 15(4), 287-291. http://dx.doi.org/10.1037/0893-164X.15.4.287

Wen, T.-H., Tchong, W.-L., \& Ching, G. S. (2014). A study on the relationship between college students' personality and their eating habits. International Journal of Information and Education Technology, 5(2), 146-149. Advanced Online Publication. Retrieved October 15, 2014, from http://dx.doi.org/10.7763/IJIET.2015.V5.492

Yang, S. C. (2012). Attitudes and behaviors related to academic dishonesty: A survey of Taiwanese graduate students. Ethics and Behavior, 22(3), 218-237. http://dx.doi.org/10.1080/10508422.2012.672904

Zaleski, E. H., Levey-Thors, C., \& Schiaffino, K. M. (1998). Coping mechanisms, stress, social support, and health problems in college students. Applied Developmental Science, 2(3), 127-137. http://dx.doi.org/10.1207/s1532480xads0203_2

Zhang, J.-M. (2008). Problems and solutions related to college students' belief. International Education Studies, 1(3), 95-98. http://dx.doi.org/10.5539/ies.v1n3p95 